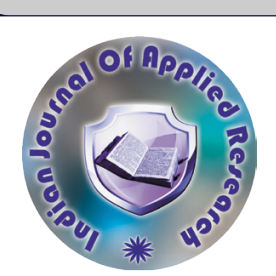

Paediatrics

\title{
AN OBSERVATIONAL STUDY OF HEARING IMPAIRMENT IN CHILDREN BELOW 12 YEARS OF AGE AT A TERTIARY CARE CENTRE
}

\section{Dr. Jigisha Patadia* \\ Dr. Santoshi Subhadarsini}

M. D. (Pediatrics), Additional Professor, Department of Pediatrics, Government Medical College, Surat. *Corresponding Author

ABSTRACT Background: Hearing is the key to learning spoken language and is important for the cognitive development of children. Without suitable interventions, hearing loss is a barrier to both education and social integration. Untreated hearing loss also affects social and economic development in communities and countries. Objectives: 1 . To identify the proportion of different etiologies of hearing impairment in children below 12 years of age. 2 . To evaluate association of perinatal, early and late childhood factors with hearing impairment in children below 12 years of age. Methods: A descriptive cross-sectional study conducted in children younger than 12 years of age attending tertiary care center of South Gujarat for hearing impairment. Total 214 patient's records out of them 34 patients were lost to follow-up and 15 patients did not give consent for the study. So total 165 patients included in study. Results: Total 165 patients out of them $69.2 \%$ had Sensorineural hearing loss and $30.8 \%$ had conductive hearing loss. Most common cause of hearing impairment are ear infection followed by prematurity, chromosomal defect and history of NICU stay. Conclusion: Most common type of hearing loss is Sensorineural hearing loss and most common cause of hearing impairment is ear infection followed by prematurity, chromosomal defect and history of NICU stay.

\section{KEYWORDS : Hearing Impairment; Perinatal causes}

\section{INTRODUCTION}

The interaction between a person and his or her surrounding environment is mediated through sensory experiences. The sense of hearing, in particular, fundamentally facilitates communication and fosters social interaction. Hearing is the key to learning spoken language and is important for the cognitive development of children. Without suitable interventions, hearing loss is a barrier to both education and social integration. ${ }^{[1]}$ Effects of hearing loss on the development of child's ability to learn, to communicate and to socialize can be devastating. Untreated hearing loss is often associated with academic underachievement, which can lead to reduced employment opportunities later in life. ${ }^{[2]}$ Communication difficulties can have lasting emotional and psychological consequences that can lead to feelings of isolation, loneliness and depression. ${ }^{[3,4]}$ The impact on the family is equally profound. The stress can be further exacerbated by communication difficulties with their children and increased need for support and financial resources. ${ }^{[5]}$ Untreated hearing loss also affects social and economic development in communities and countries.

Worldwide approximately 360 million people have hearing disorders and nearly 32 million of them are children. ${ }^{[6]}$ Overall prevalence of congenital hearing disorder is 1-3 per 1000 newborns. As per WHO estimates in India, there are approximately 63 million people who are suffering from significant hearing impairment; this places the estimated prevalence at $6.3 \%$ in Indian population. ${ }^{[7]}$ In developing countries the technology of early diagnosis, effective hearing aids, cochlear implants, education in special schools \& other rehabilitative measures are not adequately distributed. This leads to delayed diagnosis of congenital hearing losses. In India this problem has started to be addressed just now with advent of National Programme for prevention and control of deafness according to operational 12th five year plan. However it is not effectively implemented throughout India till date. ${ }^{[8]}$

It is estimated that over $60 \%$ of such hearing loss could be avoided through preventive measures. In addition, children who have hearing loss can benefit greatly from early identification and appropriate interventions. Action is required to ensure that the preventable causes of hearing loss are avoided and that everyone with unavoidable hearing loss can reach their full potential through rehabilitation, education and empowerment. Early identification and intervention can significantly help decide and prioritize the areas of active intervention as healthcare providers to children in need of it. This study outlines the prevalence and common risk factors of childhood hearing loss and need of preventive measures to deal with the same. This study would help in creating awareness, establishing multidisciplinary prediction screening model for at risk babies.

\section{AIMS AND OBJECTIVES}

1. To identify the proportion of different etiologies of hearing impairment in children below 12 years of age.

2. To evaluate association of perinatal, early and late childhood factors with hearing impairment in children below 12 years of age.

\section{MATERIALS AND METHODS}

Population of the study are all Children below 12 years age coming at Department of Paediatrics and Department of ENT, New Civil Hospital Surat during $1^{\text {st }}$ January 2017 to $30^{\text {th }}$ June 2018. The present study was a cross sectional study conducted in New Civil Hospital Surat. The study was carried out from January 2017 to June 2018.

Sample size: All children below 12 years of age coming to OPD at Department of Paediatrics and Department of ENT, New Civil Hospital Surat during $1^{\text {st } J a n u a r y ~} 2017$ to $30^{\text {th }} J$ June 2018.

\section{INCLUSION CRITERIA:}

1. All children below 12 years of age coming to OPD directly with complaints of reduced or difficulty in hearing.

2. Children below 12 years of age; having high risk factors;(Enumerated in methodology) presenting to Department of

Paediatrics with complaints of reduced or difficulty in hearing.

\section{EXCLUSION CRITERIA:}

1. Those children whose parents give negative consent for the study.

2. Those patients who, on being contacted, don't come for examination

3. Patients with active inflammation of external ear and impacted wax in external auditory canal.

Sampling method and sample selection: A descriptive crosssectional study conducted in children younger than 12 years of age attending tertiary care center of South Gujarat for hearing impairment. Total 214 patient's records out of them 34 patients were lost to followup and 15 patients did not give consent for the study. So 165 patients; who were satisfying the inclusion criteria; were included into present study. Details of patients such as age, gender, history of infection and genetic disease, ear abnormality, hearing condition collected.

Ethical Clearance: Ethical approval was taken before the commencement of the study from the ethical committee of the concerned institution.

\section{Method of data collection:}

A pretested semi structured questionnaire was used to interview a respondent from the family.A brief history comprising of presenting complaints, any significant past history or family history was obtained.Patient was then subjected (with consent of the guardian or parents accompanying the patient) to a general physical examination 
and systemic examination.After the above said procedure, patient was referred to the Department of ENT for further evaluation.The patients was evaluated by the audiologist and confirmed as hearing impaired.Patients who are lost in follow up, don't have good recall of events and who have no valid records will be excluded from the study.Patients remaining at the end of our study were analyzed and conclusions were drawn accordingly.

\section{STATISTICALANALYSIS:}

The data entry wasdone using Microsoft Office Excel 2016and data analysis was done using Microsoft Office Excel 2016 and IBM SPSS version 21 .

\section{RESULTS}

A descriptive cross-sectional study conducted in children younger than 12 years of age attending tertiary care center of South Gujarat for hearing impairment. Total 165 patients; who were satisfying the inclusion criteria; were included into present study.

Table 1: Age and Gender wise distribution of all patients

\begin{tabular}{|c|c|c|c|}
\hline \multirow{2}{*}{$\begin{array}{c}\text { Age groups } \\
\text { (Years) }\end{array}$} & \multicolumn{2}{|c|}{ Gender } & \multirow{2}{*}{ Total (\%) } \\
\cline { 2 - 3 } & Male (\%) & Female (\%) & \\
\hline $\mathbf{0}-\mathbf{1}$ & $10(9.1)$ & $7(12.7)$ & $17(10.3)$ \\
\hline $\mathbf{1}-\mathbf{3}$ & $30(27.3)$ & $16(29.1)$ & $46(27.9)$ \\
\hline $\mathbf{3}-\mathbf{6}$ & $23(20.9)$ & $8(14.5)$ & $31(18.8)$ \\
\hline $\mathbf{6}-\mathbf{1 2}$ & $47(42.7)$ & $24(43.6)$ & $71(43.0)$ \\
\hline Total & $110(100.0)$ & $55(100.0)$ & $165(100.0)$ \\
\hline
\end{tabular}

Table 1 show that mean age of the patients was $5.6 \pm 3.4$ years with minimum age 6 months and maximum age 12 years. Two-thirds of the patients $(66.7 \%)$ were males $(n=110)$ and remaining $33.3 \%$ patients were females $(n=55)$ with male - female ratio of $2: 1$. Between both male patients $(n=110)$ and female patients $(n=55)$, majority of the patients were $6-12$ years old $(42.7 \%)$ and (43.6\%) respectively.

Table 2: Distribution of patients based on history of infection and complication history during birth

\begin{tabular}{|l|l|l|}
\hline Characteristics & Number & Percentage \\
\hline History of infection & & \\
\hline Meningitis & 17 & $10.3 \%$ \\
\hline Cytomegalovirus (CMV) & 5 & $3.0 \%$ \\
\hline Rubella & 1 & $0.6 \%$ \\
\hline No infection & 142 & $86.1 \%$ \\
\hline Complication history during birth & & \\
\hline Perinatal Asphyxia & 24 & $14.5 \%$ \\
\hline Neonatal jaundice & 13 & $7.9 \%$ \\
\hline Prematurity $(<28$ weeks $)$ & 13 & $7.9 \%$ \\
\hline Very low birth weight $(<1500 \mathrm{gm})$ & 8 & $4.8 \%$ \\
\hline
\end{tabular}

Table 2 show that majority of the patients ( $86.1 \%)$ had no history of infection. However, $10.3 \%$ patients had history of meningitis, $3 \%$ patients had history of CMV infection and $0.6 \%$ patients had history of Rubella infection. Multiple complications were present during birth in different patients and many of them were overlapping. Table II show that $14.5 \%$ patients had history of perinatal asphyxia, $7.9 \%$ had neonatal jaundice, $7.9 \%$ patients were premature at birth and $4.8 \%$ patients had history of very low birth weight.

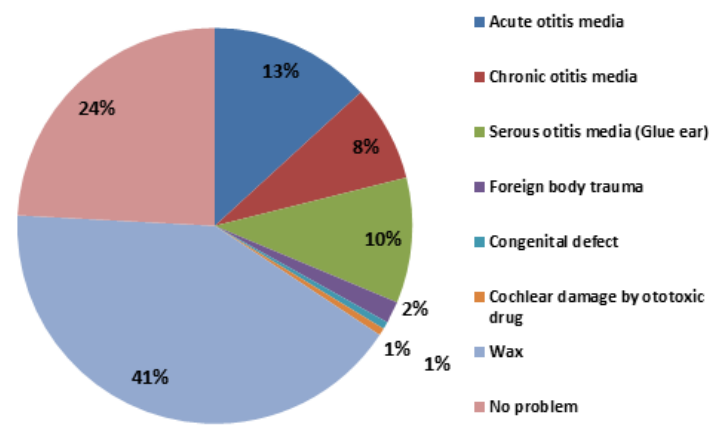

Chart 1: Distribution of patients based on Problems in Ear

Above chart show, that majority of the patients (41.8\%) had wax in ear. However, $13.3 \%$ patients had acute otitis media, $7.9 \%$ patients had chronic otitis media, $10.3 \%$ patients had serous otitis media (Glue ear), $1.8 \%$ patients had foreign body trauma, $0.6 \%$ had congenital defect and $0.6 \%$ had Cochlear damage by ototoxic drug. While $24.3 \%$ patients had no damage in ear $(n=39)$.

Different audiological tests were performed for evaluation of hearing loss in all patients. Pure tone audiometry (PTA) was performed in $57.6 \%$ patients $(n=95)$, Free field audiometry was performed in $25.5 \%$ patients $(n=42)$, Impedance audiometry was performed in $4.2 \%$ patients $(n=7)$, Otoacoustic Emission was performed in $26.7 \%$ patients $(n=44)$ and Brainstem Evoked response audiometry (BERA) was performed in $13.9 \%$ patients $(n=23)$.

Table 3: Distribution of patients based on Hearing condition

\begin{tabular}{|c|c|c|c|c|}
\hline Hearing condition & $\begin{array}{c}\text { Both ear } \\
(\mathbf{\%})\end{array}$ & $\begin{array}{c}\text { Right ear } \\
(\mathbf{\%})\end{array}$ & $\begin{array}{c}\text { Left ear } \\
(\mathbf{\%})\end{array}$ & Total (\%) \\
\hline Normal hearing & $23(65.7)$ & $4(11.4)$ & $8(22.9)$ & $35(100.0)$ \\
\hline $\begin{array}{c}\text { Conductive } \\
\text { hearing loss }\end{array}$ & $21(52.5)$ & $12(30.0)$ & $7(17.5)$ & $40(100.0)$ \\
\hline $\begin{array}{c}\text { Sensorineural } \\
\text { hearing loss }\end{array}$ & $60(66.7)$ & $17(18.9)$ & $13(14.4)$ & $90(100.0)$ \\
\hline $\begin{array}{c}\text { Mixed hearing } \\
\text { loss }\end{array}$ & 0 & 0 & 0 & 0 \\
\hline
\end{tabular}

Table 3 shows that Total 165 patients out of them 35 patients had normal hearing, among them $65.7 \%$ had normal hearing in both ears, $11.4 \%$ had normal hearing in right ear and $22.9 \%$ had normal hearing in left ear. While 40 patients had Conductive hearing loss (CHL), among them $52.5 \%$ had conductive' hearing loss in both ears, $30 \%$ had conductive hearing loss in right ear and $17.5 \%$ had conductive hearing loss in left ear, and 90 patients had Sensorineural hearing loss (SNHL), among them $66.7 \%$ had SNHL in both ears, $18.9 \%$ had SNHL in right ear and $14.4 \%$ had SNHL in left ear. Conversely, none of the patients had mixed hearing loss.

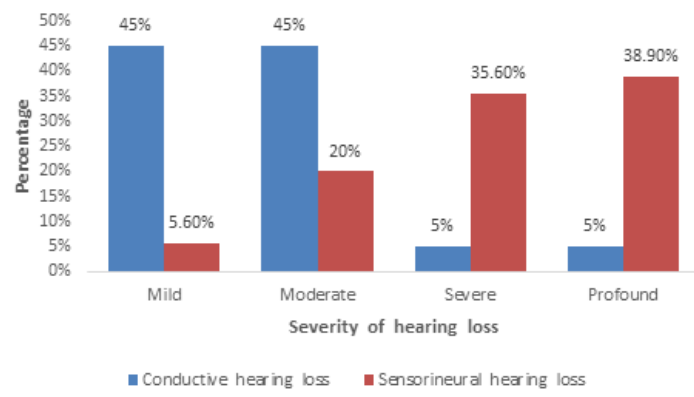

Chart 2: Distribution of patients based on Conductive hearing loss and sensorineural hearing loss

Chart 2 shows that Among the patients who had conductive hearing loss(CHL), $45.0 \%$ had mild CHL, $45.0 \%$ had moderate CHL, $5.0 \%$ had severe CHL and 5.0\% had profound CHL and Among the patients who had Sensorineural hearing loss (SNHL), 5.6\% had mild SNHL, $20.0 \%$ had moderate SNHL, 35.6\% had severe SNHL and $38.9 \%$ had profound SNHL. This difference is statistically significant. $(\mathrm{P}$ value $=$ 0.0001 )

Table 4: Distribution of patients based on Hearing condition in different clinical condition

\begin{tabular}{|c|c|c|c|c|c|}
\hline \multirow{2}{*}{$\begin{array}{c}\text { Clinical } \\
\text { condition }\end{array}$} & \multicolumn{2}{|c|}{ Hearing condition } & \multirow{2}{*}{\begin{tabular}{|l} 
Total \\
$(\%)$
\end{tabular}} & \multirow{2}{*}{$\begin{array}{c}P \\
\text { value }\end{array}$} & \multirow{2}{*}{$\begin{array}{c}\text { Chi } \\
\text { square }\end{array}$} \\
\hline & $\begin{array}{l}\text { Hearing } \\
\text { loss }(\%)\end{array}$ & \begin{tabular}{|c|} 
Normal \\
hearing $(\%)$
\end{tabular} & & & \\
\hline $\begin{array}{l}\text { Chromosomal } \\
\text { defect }(n=33)\end{array}$ & $19(57.6)$ & 14 (42.4) & $\begin{array}{c}33 \\
(100)\end{array}$ & 0.0008 & 11.106 \\
\hline $\begin{array}{c}\text { History of } \\
\text { infection in } \\
\text { patients }(n=23)\end{array}$ & $9(39.0)$ & $14(61.0)$ & $\begin{array}{c}23 \\
(100)\end{array}$ & 0.0001 & 25.15 \\
\hline $\begin{array}{c}\text { Perinatal } \\
\text { Asphyxia }(n=24)\end{array}$ & $9(37.5)$ & $15(62.5)$ & $\begin{array}{c}24 \\
(100)\end{array}$ & 0.0001 & 28.64 \\
\hline $\begin{array}{c}\text { Neonatal } \\
\text { jaundice }(n=13)\end{array}$ & $6(46.2)$ & $7(53.8)$ & $\begin{array}{c}13 \\
(100)\end{array}$ & 0.008 & 6.99 \\
\hline $\begin{array}{c}\text { Prematurity } \\
(n=13)\end{array}$ & $8(61.5)$ & $5(38.5)$ & $\begin{array}{c}13 \\
(100)\end{array}$ & 0.2 & 1.51 \\
\hline $\begin{array}{c}\text { Very low birth } \\
\text { weight }(n=8)\end{array}$ & $4(50.0)$ & $4(50.0)$ & $\begin{array}{c}8 \\
(100) \\
\end{array}$ & 0.1 & 2.56 \\
\hline $\begin{array}{c}\text { Ear infection } \\
(n=52)\end{array}$ & $38(73.1)$ & $14(26.9)$ & $\begin{array}{c}52 \\
(100) \\
\end{array}$ & 0.22 & 1.48 \\
\hline
\end{tabular}

INDIAN JOURNAL OF APPLIED RESEARCH 


\begin{tabular}{|c|c|c|c|c|c|}
\hline \hline $\begin{array}{c}\text { NICU stay } \\
(\mathbf{n}=\mathbf{6 9})\end{array}$ & $38(55.1)$ & $31(44.9)$ & $\begin{array}{c}69 \\
(100)\end{array}$ & 0.0001 & 39.91 \\
\hline $\begin{array}{c}\text { Microcephaly } \\
(\mathbf{n}=\mathbf{6 8})\end{array}$ & $33(48.5)$ & $35(51.5)$ & $\begin{array}{c}68 \\
(100)\end{array}$ & 0.0001 & 63.36 \\
\hline $\begin{array}{c}\text { Abnormal Facies } \\
(\mathbf{n}=\mathbf{3 8})\end{array}$ & $23(60.5)$ & $15(39.5)$ & $\begin{array}{c}38 \\
(100)\end{array}$ & 0.001 & 9.85 \\
\hline
\end{tabular}

Among patients who had history of chromosomal defect, $57.6 \%$ had decreasing hearing.In patients who had history of infection such as meningitis, CMV and Rubella infection, 39\% had hearing loss. In patients who had history of perinatal asphyxia, 37.5\% had develop hearing loss.In Patients with history of neonatal jaundice, $46.2 \%$ had develophearing loss. In patients who require NICU admission, 55.1\% developed hearing loss. Among patients who had microcephaly, $48.5 \%$ developed hearing loss.In patients with abnormal facies, $60.5 \%$ had developed hearing loss. This all-clinical condition are statistically significant.

\section{DISCUSSION}

The age group ranged from 6 month to 12 years with mean age of $5.6 \pm$ 3.4 years and $43 \%$ of children were from $>6$ years age group. These figures are in close agreement with Pawde A et al study in which majority of children $(44 \%)$ were from $>5-9$ years age group.

In the present study, there were $66.7 \%$ males and $33.3 \%$ females with male to female ratio of $2: 1$. Such male predominance is widely reported in literature with Pawde A et al ${ }^{[9]}$ and Bhadauria et al ${ }^{[10]}$ study. The reason of this male preponderance in deaf mutism might be related to genetics or biased care towards girl child. The male child is express or of genes in dominant, recessive as well as sex linked transmission. Male children are also more susceptible to adverse factors acting in prenatal, natal, postnatal life, though the reason for this has not been identified.

In present study, $10.3 \%$ patients had history of meningitis, $3 \%$ patients had history of CMV infection and $0.6 \%$ patients had history of Rubella infection. Similar result was reported by Holborow et al. ${ }^{[1]}$ and A. D. Dunmade $^{[12]}$ wherein the main acquired causes of hearing loss were measles and meningitis followed by mumps and rubella. In study published by Karanja et al, ${ }^{[13]} 83$ children were assessed following bacterial meningitis of which $44.4 \%$ had hearing loss.

In the present study the most common complication during Birth was perinatal asphyxia $(14.5 \%)$ followed by neonatal jaundice $(7.9 \%)$, premature at birth $(7.9 \%)$ and very low birth weight history $(4.8 \%)$. Similar findings was revealed by Zhiqi Liu and Lisi Liu et al ${ }^{[1 / 4]}$ study in which jaundice and neonatal asphyxia coexisting in most cases followed by premature birth and low birth weight. Contrast to our study prematurity was predominant complication in study conducted by Mary James et al ${ }^{[15]}$ and Mallikarjun et al. ${ }^{[16]}$

The most consistent type of lesion responsible for deafness in our study was wax $(41.8 \%)$, followed by acute otitis media $(13.3 \%)$, chronic otitis media $(7.9 \%)$, and serous otitis media(10.3\%). This figure closely resembles the study by Saud Lateef Chishty et $\mathrm{al}^{[17]}$ who observed that out of all cases of hearing impairment in children, $41.94 \%$ were having wax. Foreign body trauma, congenital defect and Cochlear damage by ototoxic drug were less common in present study. However in study published by Saud Lateef Chishty et $\mathrm{al}^{[17]}$ and Ambrish Kumar et $\mathrm{al}^{[18]}$, chronic suppurative otitis media is more prevalent followed by otitis media with effusion.

In the present study, predominantly performed audiological test was Pure Tone Audiometry (57.6\%) followed by Otoacoustic Emission $(26.7 \%)$, Free Field Audiometry(25.5\%), BERA(13.9\%) and Impedance Audiometry(4.2\%). The methods used for audiological testing in Mary James et al ${ }^{[15]}$ study were Otoacoustic Emission(OAE) and Brainstem Evoked Response Audiometry(BERA). Wherein Ambrish Kumar et al ${ }^{[18]}$ study children were examined using Pure Tone Audiometry(PTA) and Tympanometry.

Total 130 patients out of 165 patients had hearing loss, among them $69.2 \%$ had Sensorineural hearing loss, $30.8 \%$ had Conductive hearing loss and none of the patients had mixed hearing loss. Similar findings was reported by Holborow et al. ${ }^{[11]}$ wherein $60.8 \%$ of children had sensorineural type of hearing loss. Contrast to our study, Saud Lateef Chishty et $\mathrm{al}^{[17]}$ and Satish S. Raju ${ }^{[19]}$ noted that in children most common type of hearing loss is of conductive type. This may be due to the difference in the inclusion of type of underlying risk factors in both the studies.
Among the patients who had conductive hearing loss, the degree of deafness found most commonly was mild and moderate degree of deafness, it constituted $90 \%$ cases. Severe and profound deafness was found only in rest $10 \%$ cases. This is in agreement with Saud Lateef Chishty et al ${ }^{[17]}$ and Niskar et al. ${ }^{[20]}$ who found that most of the children were having low frequency hearing loss.

Among patients who had history of chromosomal defect, $57.6 \%$ had decreasing hearing. The fact that genetic hearing loss is commonest cause of congenital and early hearing loss has also been reported by Wiley et al ${ }^{[21]} 51.5 \% .8$ The findings in present study correlate well with those reported in Kalsotra et $\mathrm{a}^{[22]}$ study in which they found genetic causes of hearing loss to be $47.5 \% .6$

In Present study among the prenatal cause, patient with history of infection such as meningitis, CMV and Rubella infection, 39\% had hearing loss. Which was in accordance with in study done by Singh et al. ${ }^{[23]}$ and Abolfotouch et al ${ }^{[24]}$ This difference might indicate level of care of expectant mother.

Among the perinatal causes, patients who require NICU admission, $55.1 \%$ developed hearing loss and patients who had facial abnormality, $64.2 \%$ developed hearing loss. Which was in accordance with Pawde A et $\mathrm{al}^{[9]}$ and Elangos et $\mathrm{al}^{[25]}$ study, whose incidence was second highest. $^{[11]}$

Among the perinatal causes, patients who had history of perinatal asphyxia, $37.5 \%$ had developed hearing loss and patients with history of neonatal jaundice, $46.2 \%$ had developed hearing loss. Which is in accordance with various studies like Pawde A et al and Abolfotouch et al. ${ }^{[10]}$

In the present study idiopathic causes contributed to most of cases which from preventable causes of hearing loss and can be improved by improving standard of obstetrics and neonatal care. This will require very concern efforts, in form of genetic counseling.

\section{CONCLUSION}

Most common type of hearing loss in present study is Sensorineural hearing loss and none of the patients had mixed hearing loss. The degree of deafness found most commonly was severe and profound degree of deafness. Most common cause of hearing impairment found in this study is due to ear infection followed by prematurity, chromosomal defect and history of NICU stay.

Hearing loss due to neonatal jaundice, NICU admission, prematurity, birth asphyxia and other acquired causes can be partially preventable by the screening and extra care towards children. So protocol for early hearing assessment, genetic counseling of partners in consanguineous marriages and public awareness about causes and rehabilitation should be emphasized.

\section{REFERENCE}

1. Yoshinaga-Itano C, Seday AL, Coulter DK, Mehl AL. Language of early- and late identified children with hearing loss. Pediatrics. 1998; 102(5): 1161-71

2. Olusanya BO, Neumann KJ, Saunders JE. The global burden of disabling hearing impairment: a call to action. Bulletin of the World Health Organization. 2014; 92(5): $367-73$.

3. Theunissen SC, Rieffe C, Netten AP, Briaire JJ, Soede W, Schoones JW, Frijns JH. Psychopathology and its risk and protective factors in hearing-impaired children and adolescents: a systematic review. JAMA Pediatrics. 2014; 168(2): 170-177.

4. Stevenson J, McCann D, Watkin P, Worsfold S, Kennedy C. The relationship between language development and behaviour problems in children with hearing loss. Journal of language development and behaviour problems in children with hearing loss. J
Child Psychology and Psychiatry and Allied Disciplines. 2010;51(1):77-83.

5. Zaidman-Zait A, Most T, Tarrasch R, Haddad-Eid E, Brand D. The impact of childhood hearing loss on the family: mothers' and fathers' stress and coping resources. Journal of Deaf Studies and Deaf Education. 2015;21(1): 23-33.

6. Prevention of blindness and deafness: estimates. Geneva:World Health Organization;2015 (http://www.who.int/pbd/deafness/estimates/en/; accessed 11 December 2015).

7. Mortality and Burden of Diseases and Prevention of Blindness and Deafness WHO, 2012

8. Disability India J. 2006, April 04 edition.

9. Pawde A, Chaurpagar R, Aggarwal S, Agarwal A, Dabhekar S. A cross sectional study of clinical profile of deaf mute children at tertiary care center. Int J Otorhinolaryngol Head clinical profile of

10. Bhadauria RS, Nair S, PalDK. A Survey of deaf mutes. Med J Armed Forces India. 2007;63(1):29-32

11. Profound Bilateral Sensorineural Hearing Loss in Nigerian Children: Any Shift in Etiology; Journal of Deaf Studies and DeafEducation 12:1 Winter 2007:112-118

12. A. D. Dunmade S. Segun-Busari T. G. Olajide F. E. Ologe. Profound Bilatera Sensorineural Hearing Loss in Nigerian Children: Any Shift in Etiology? J Deaf Stud Deaf Educ. 2007 Winter; 12(1):112-8. Epub 2006 Sep 6.

13. Benson Wahome Karanja, Herbert Ouma Oburra, Peter Masinde, Dalton Wamalwa Prevalence of hearing loss in children following bacterial meningitis in a tertiary referral hospital. BMC Research Notes 2014, 7:138

14. Zhiqi Liu and Lisi Liu. Hearing screening and diagnosis in a large sample of infants in Central China. J Med Screen 2013;20:21-26.

15. Mary James, Kumar P., Praveen Jacob Ninan. A study on prevalence and risk factors of 

hearing impairment among newborns. IJCP 20180018.

16. Mallikarjun Patil, Prakash Handi, K. R. Prasenkumar, Kranti Gouripur. Objective screening of hearing impairment using brainstem evoked response audiometry in children below 5 years of age and assessing the high risk factors. Int J Otorhinolaryngol Head Neck Surg. 2018 Jul;4(4):923-926.

17. Chishty SL, Hamid S, Esbah-i-Lateef, Chishty ML, Wani A, Najeeb Q. A prospective study of hearing impairment in school going children of Ghaziabad city attending a tertiary care hospital. Int J Res Med Sci 2014;2:1127-33.

18. Ambrish Kumar. A cross-sectional study to assess hearing impairment in school going Ambrish Kumar. A cross-sectional study to assess hearing impairment in school going
children aged 6 to10 years of Ranchi City.

19. Satish S. Raju and Thanzeemunisa. The incidence of hearing loss in Down's Syndrome:A clinicoaudiological study. Journal of Evolution of Medical and Dental Sciences. 4(78):13721-13737. September 2015 .

20. Niskar AS, Kieszak SM, Holmes A, Eskban E, Rubin C, Brody DJ. Prevalence of hearing loss among children 6 to 19 years of age: the third national health and nutrition examination survey. JAMA. 1998;279(14):1071-5.

21. Wiley S, Arjmand E, Jareenmeinzen-Derr, Dixon M. Findings from multidisciplinary evaluation of children with permanent hearing loss. Int J Pediatr Otorhinolaryngol. 2011;75:1040-4.

22. Kalsotra P, Kumar S, Gosh P, Mishra NK, VermaIC. A Study of Congenital and Early Acquired Impairment of hearing. J K Sci. 2002;4:136-43.

23. Singh M, Gupta SC, Singla A. Assessment of deafmute patients:a study of ten years. Ind Singh M, Gupta SC, Singla A. Ass

24. Abolfotouh MA, AI-Ghamdi SA. The pattern of hearing impairment among schoolboys in an Institute for deaf subjects. Saudi Med J. 2000;21:873-6. Elango S, Chand RP, Purohit GN. Childhood deafness in Malaysia. Int J Pediatr Otorhinolaryngol. 1992;24:11-7 